\title{
INFLUENCE OF GOVERNMENT POLICIES ON THE FINANCIAL PERFORMANCE OF SACCOS IN IMENTI NORTH SUB-COUNTY, KENYA
}

\author{
Phineas Muriungi Muguna \\ School of Business and Economics, Kenya Methodist University \\ Fredrick Mutea \\ School of Business and Economics, Kenya Methodist University \\ Dr. Ken Mugambi, PhD \\ School of Business and Economics, Kenya Methodist University \\ http://doi.org/10.35409/IJBMER.2020.3196
}

\begin{abstract}
The main goal of starting SACCO's is to mobilize funds in order to advance credit to clients. Funds are mainly mobilized from savings by customers who mainly provide a stable source of low cost funding. Cooperatives are one of the pillars supporting Kenya's economic growth since independence. It is reported that mismanagement, ethnicity and corruption are the most significant factors affecting the performance of SACCOs, various studies have been carried and the researches dwelt on the power of financial ratios in detecting fraudulent financial reporting in SACCOs. This study focuses on analyzing the factors affecting the financial performance of SACCOs in Imenti North Sub-County. SACCOs are expected to empower their members through mobilization of savings and provision of credit to their members. The study objective was to establish the influence of government policies on the financial performance of SACCOs in Imenti North Sub-County. The study adopted a descriptive survey research design and the target population of the study was 108 management staff from all the 34 registered Sacco's in Imenti North Sub- County and which were registered with the district cooperative office by January 2019 to conduct business as Sacco's. These management employees in the Sacco's included Sacco managers, credit managers and credit officers. The results showed that there is positive influence of government policies on financial performance in SACCO's. This shows that government policies have a positive influence on financial performance in Sacco's. The study concluded that there are many conflicting policies from the ministry of cooperatives and Sasra which affects financial performance of Sacco's and that Sacco's are operating in financial distress which is affecting their financial performance. The study recommended that Sacco's should develop internal policies that does not conflict SASRA policies.
\end{abstract}

Keyword: Influence, Government Policies, Financial Performance, Saccos.

\section{INTRODUCTION}

The financial performance in SACCO's started in 1852 when Herman Frank consolidated two pilot projects in Germany into credit unions. In 1864 another Germany, Raiffeisen founded the first Sacco in rural Germany to cater for the needs of people with low income. The low income 


\section{International Journal of Business Management and Economic Review}

Vol. 3, No. 04; 2020

ISSN: 2581-4664

communities were considered unbankable because of very small and seasonal cash flows. Since then, there has been a rapid growth in the cooperative movement worldwide based on the organizational methods of Raiffeisen (Bassem 2008).

The main goal of starting SACCO's is to mobilize funds in order to advance credit to clients. Funds are mainly mobilized from savings by customers who mainly provide a stable source of low cost funding. Administrative costs of such savings are also low and hence SACCOs are able to advance credit at low interest rates to its clients as opposed to mainstream financial institutions such as banks whose cost of funding and administration of savings is high. Furthermore, SACCOs are accessible to a wide range of customers in remote areas which are considered untenable to other financial institutions such as commercial banks. Consequently, SACCOs have been able to entrench into financial industry of many countries as preferable financial service provider in many countries (Musyimi, 2010). The main goal of SACCOs is to empower members via saving mobilization and credit provision. Nonetheless, SACCOs have not successful attained this core goal especially the part of credit provision (Musyimi, 2010).

In Kenya, 30\% of total savings (Kshs.200 billion) were mobilized by SACCOs (Cooperative Bank of Kenya, 2010). Thus, SACCOs are instrumental in Kenyan financial industry. It is estimated that SACCOs accounts for approximately $45 \%$ of Kenyan GDP. The requirement that credit applicants need social security may hinder access to loans (Ndungu, 2010). This may reduce members' ability to invest in capital intensive ventures which are most often profitable. The realization of the Kenya Vision 2030 is pegged on the ability of financial institutions, including SDACCOs, to mobilize funds and extent credit to their members to spur development through investment

Cooperatives are one of the pillars supporting Kenya's economic growth since independence. It is reported that mismanagement, ethnicity and corruption are the most significant factors affecting the performance of SACCOs, various studies have been carried and the researches dwelt on the power of financial ratios in detecting fraudulent financial reporting in SACCOs e.g. Leonard Rang'alla (2009). This study focuses on analyzing the factors affecting the financial performance of SACCOs in Imenti North Sub-County.

Imenti North Sub-county is home to about 34 SACCOs. This is the highest in Meru County. Nonetheless, members belonging to these SACCOs often seek loans from other financial institutions pother than SACCOs (Omboi et. al., 2011). Making credit accessible in SACCOs can help in empowering members and hence spurring growth of various regions including Imenti North Sub-County.

\section{Statement of the Problem}

SACCOs are expected to empower their members through mobilization of savings and provision of credit to their members. This ensures that SACCOs are sustainable and are able to adopt good financial practices. Nonetheless, SACCOs are unable to efficiently raise capital through fund mobilization. This is made worse through inability of SACCOs to effectively and efficiently manage debts, liquidity and generally poor management of these entities. Despite this, SACCOs are capable of offering low priced loans which are competitive in financial industry that can allow the SACCOs to improve their financial performance (Mulwa, 2013). 


\section{International Journal of Business Management and Economic Review}

Vol. 3, No. 04; 2020

ISSN: 2581-4664

In spite of the fact that the demand for SACCOs' financial services has increased, the general financial performance of these firms decreased to $9.1 \%$ in 2016 from 13.5\% in 2013 (Central Bank of Kenya, 2016). This decline indicates that financial performance of SACCOs in Kenya is in turmoil. This decline of about $4.4 \%$ within a span of three years calls for the need of a study to be conducted in order to evaluate factors affecting the financial performance of SACCOs. It is through the interest earned from credit advancement which is used to meet the operations and administration expenses and facilitates smooth running of the SACCO's by ensuring there is enough funds for recurrent operations.

\section{Objective}

To establish the influence of government policies on the financial performance of SACCOs in Imenti North Sub-County.

\section{Research Hypothesis}

Ho. There is no significant relationship between government policies and the financial performance of SACCOs in Imenti North Sub-County.

\section{Scope of the Study}

The study was based in Imenti North Sub-County which is in Meru County. According to the Imenti North Sub-County Cooperative Office records (January 2017), there are about 34 registered Sacco's within Imenti North Sub-County which engage in various activities including disbursement of credits to its members. All these Sacco's will be covered in the study. The study targeted all the management level staff in all the Sacco's. There were 108 management level staff who included the Sacco manager, credit manager and the credit officer in all the 34 Sacco's and they were used in the study.

\section{LITERATURE REVIEW Agency theory}

Bowie et al. (1992) asserts that an agency association emerges when a single or more persons, referred to as principals, employ a single or more persons, referred to as the agents, to provide a service and then give decision making power to the agents. The primary agency association in a firm is between the management and shareholders. This association is often problematic and the main concern of agency theory is the conflict that arises between the principal and the agents. This often impacts on the way the affairs of a firm are carried out. Agency association often results in agency costs to maintain the relationship. In the case of shareholder and management relationship, agency costs may entail provision of bonuses to the management to encourage them to perform better.

According to Bowie et al. (1992) where capital and labor markets are imperfect, managers often tend to optimize their own interest rather than shareholders' utility. The management of a firm often takes advantage of information asymmetry to carry out the transactions of the organization at their own interest instead of the interest of the firm. The information asymmetry ensures that the management is at a better position to know whether they can meet the interests of the owners of the firm or not and they understand market uncertainty than the shareholders. 


\section{International Journal of Business Management and Economic Review}

Vol. 3, No. 04; 2020

ISSN: 2581-4664

In line with the theory of agency, SACCO members are the principal while SACCO management are the agents who are expected to carry out the daily running of the SACCO on behalf of members. One of the assumptions of the agency theory is that both the principal and the agent are motivated by their own interests. Thus, in the case of the SACCO the management interest may be to optimize their income while that of SACCO members may be increased dividends which emanate from better performance of the SACCO. These conflicting interest may derail the performance of the SACCOs due to the fact the management have better understanding of the operations of the SACCO and as such may result to the collapse of the SACCO if the management interest overwhelms the ability of the SACCO to meet their interests.

There exists also an agency association between the SACCO management and customers of the SACCO. In this case the management is the principal while the customers are the agents. Thus, the management seeks to ensure that the earnings of the SACCO are maximized through disbursement of loans to the clients and due to information asymmetry credit facility may be extended to customers who may be unable to service their loans. Consequently, the management may require social security in form of guarantors to reduce the risk of the debt extended to its customers. The interest charged on members can be utilised in increasing the outreach of the firm through opening of more branches. However, due to self-interest of the management in their relation with the shareholders, this may not be the case.

This self-interest of the management often results in the inability of the SACCOs to diversify their credit products and hence majority of the members may be unable to access loans from these firms. In addition, the SACCOs may not be able to offer loan products that allow clients to repay flexibly because the management want to maximize their income at the expense of shareholders and the clients. Consequently, this affects flexibility or repayment periods and procedures for loan application (Chiivakal, et al 2008).

SACCO management is charged with the responsibility of ensuring that collateral requirement is affordable to the customers and at the same time it is acceptable to the firm. This theory provides a succinct explanation as to how self-interests of the management team interferes with their purpose of ensuring they come up with innovative products to ensure better performance of SACCOs. Consequently, their interest of earning more income than the shareholders and ensuring they optimize SACCO income from customers makes majority of members to opt for other sources of credit other than the SACCO.

Government Policy

According to Wong (2010), the Sacco Societies Regulatory Authority (SASRA) is a SemiAutonomous Government Agency under the Ministry of Cooperative, Development and Marketing. It is a creation of the Sacco Societies Act 2008 and was inaugurated in 2009 charged with the prime responsibility to license and supervise deposit taking Sacco Societies in Kenya.

The foundation of SASRA falls inside the Government of Kenya's change procedure in the budgetary segment which has the double targets of securing the interests of Sacco individuals and guaranteeing that there is trust in general society towards the Sacco part and prodding Kenya's monetary development through the assembly of household investment funds. The Authority determines its forces to control the store taking Sacco Societies in Kenya from the Sacco Societies Act 2008 and the Regulations issued there under. The command of the Authority as given by the Act incorporates the accompanying; License Sacco social orders to do store 


\section{International Journal of Business Management and Economic Review}

Vol. 3, No. 04; 2020

ISSN: 2581-4664

taking business as per this act; Regulate and oversee Sacco social orders; Hold, oversee and apply the General Fund of the Authority as per the arrangements of this Act, Levy commitments as per this Act, do all such different things as might be legally coordinated by the minister and perform such different capacities as are presented on it by this act or by some other composed law.

Fig. 1 Conceptual Framework

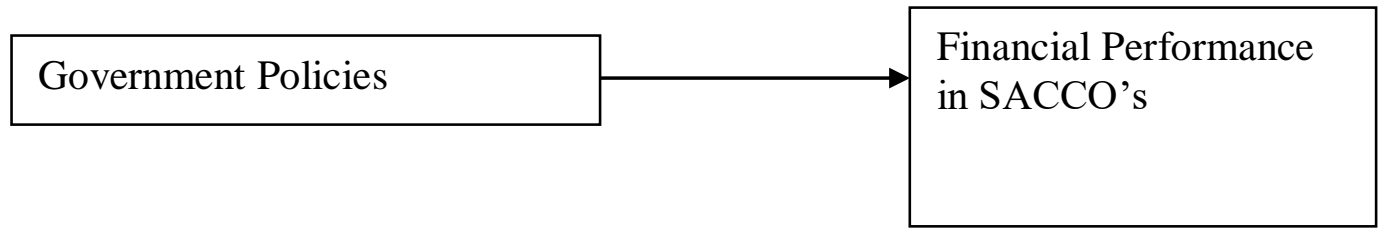

\section{RESEARCH DESIGN AND METHODOLOGY}

The study adopted a descriptive survey research design and the target population of the study was 108 management staff from all the 34 registered Sacco's in Imenti North Sub- County and which were registered with the District Cooperative Office by January 2019 to conduct business as Sacco's. These management employees in the Sacco's included Sacco managers, credit managers and credit officers. All the 34 Sacco's offer credits to their members. The researcher conducted a census of all the respondents from the Sacco's. This is because the target population is manageable and the respondents were within systems that they can be accessed. Data was collected using a structured questionnaire. Descriptive statistics was used to analyze data. The researcher will also use regression analysis to test the hypothesis of the study. The analyzed data will be presented using tables and in narrative form.

\section{RESULTS AND DISCUSSION}

The researcher issued 102 questionnaires to the respondents. Only 94 questionnaires were returned which accounted for $92 \%$ return rate. The reasons for this response rate was attributed to some of the respondents who were issued with the questionnaires returned questionnaires in time and there were well filled while very few who did not respond at all and others whose items were not filled. However, the response rate is considered adequate given the recommendations by Saunders, Lewis and Thornhill (2007) who suggested a 30-40\% response is adequate.

Table 4. 14: Response on SASRA regulations have affected the Sacco's.

\begin{tabular}{|llll|}
\hline Responses & & Frequency & Percent \\
\hline & Strongly Agree & 56 & 59.6 \\
& Agree & 6 & 6.4 \\
Disagree & 29 & 30.9 \\
& Total & 91 & 96.8 \\
\hline
\end{tabular}


Vol. 3, No. 04; 2020

ISSN: 2581-4664

\begin{tabular}{|llll|}
\hline \hline Missing & System & 3 & 3.2 \\
Total & & 94 & 100.0 \\
\hline
\end{tabular}

Source; Author (2019)

Majority of the respondents $65.4 \%$ agreed that the current Sasra regulations have affected the financial performance of Sacco's. However, 30.9\% disagreed that current Sasra regulations have affected the financial performance of Sacco's. This reveals that Sacco's are affected by the current Sasra regulations which affects their financial performance of Sacco's.

Table 4.15: There are many conflicting policies

\begin{tabular}{|lll|}
\hline Responses & Frequency & Percent \\
\hline Strongly Disagree & 5 & 5.1 \\
Disagree & 9 & 9.2 \\
Neutral & 2 & 2.2 \\
Agree & 15 & 15.4 \\
Strongly Agree & 63 & 68.0 \\
Total & 94 & 100.0 \\
\hline
\end{tabular}

\section{Source; Author (2019)}

The results indicated that $83.4 \%$ of the respondents agreed that there are many conflicting policies from the ministry of cooperatives and Sasra which affects financial performance of Sacco's while only $14.3 \%$ disagreed that there are many conflicting policies from the ministry of cooperatives and Sasra which affects financial performance of Sacco's. This means that from the majority of the respondents that there are many conflicting policies from the ministry of cooperatives and Sasra which affects financial performance of Sacco's.

Table 4.16: Sacco's have developed internal financial policies

\begin{tabular}{|cll|}
\hline Responses & Frequency & Percent \\
\hline Strongly Disagree & 7 & 7.4 \\
Disagree & 11 & 12.1 \\
Neutral & 3 & 3.3 \\
Agree & 61 & 64.0 \\
Strongly Agree & 12 & 13.2 \\
Total & 94 & 100.0 \\
\hline
\end{tabular}


Vol. 3, No. 04; 2020

ISSN: 2581-4664

\section{Source; Author (2019)}

The results indicated that $77.2 \%$ of the respondents agreed that all Sacco's have developed internal financial policies that influences financial performance while $19.5 \%$ of the respondents disagreed that all Sacco's have developed internal financial policies that influences Sacco's financial performance. This shows that Sacco's have developed internal financial policies that influences financial performance.

Table 4.17: There is adequate policies in Sacco's

\begin{tabular}{|lll|}
\hline Responses & Frequency & Percent \\
\hline Strongly Disagree & 8 & 8.8 \\
Disagree & 6 & 7.0 \\
Neutral & 3 & 3.3 \\
Agree & 53 & 55.1 \\
Strongly Agree & 24 & 25.7 \\
Total & 94 & 100.0 \\
\hline
\end{tabular}

\section{Source; Author (2019)}

The results indicated that $80.8 \%$ of the respondents agreed that there is There is adequate policies that helps the improve Sacco's financial performance while only $15.8 \%$ of the respondents stated that there is adequate policies that helps the improve Sacco's financial performance. This finding means that there is no adequate policies that helps the improve Sacco's financial performance.

Table 4.23: Correlations of the dependent and independent variables

\begin{tabular}{|llc|}
\hline \multicolumn{2}{l}{ Independent Variables } & Government Policies \\
\hline $\begin{array}{l}\text { Sacco Financial } \\
\text { Performance (Y) Pearson Correlation(r) }\end{array}$ & $.438^{*}$ \\
& Sig. (2-tailed) & .004 \\
\hline
\end{tabular}

\section{Source; Author (2019)}

\section{Test of hypothesis of Government Policies}

There is a weak positive relationship between government policies and financial performance of Sacco's in Imenti North Sub-County as indicated by correlation of 0.438 . The p-Value of 0.004 is less than the acceptable significance level $(\alpha)$, hence the null hypothesis that there is no relationship between government policies and financial performance of Sacco's in Imenti North Sub-County is rejected. This shows that the sampled data can be applied to the general population at $95 \%$ confidence level. 


\section{SUMMARY, CONCLUSIONS AND RECOMMENDATIONS}

The objective of the study was to establish the influence of government policies on financial performance in SACCO's in Imenti North Sub-County. The results showed that there is positive influence of government policies on financial performance in SACCO's. This finding is further supported by variation of 0 . 696. The p-Value of 0.002 was obtained which is less than the acceptable significance level $(\alpha)$, hence the null hypothesis that there is no relationship between government policies and financial performance of Sacco's in Imenti North Sub-County was rejected. This shows that government policies have a positive influence on financial performance in Sacco's. Sacco's in Imenti North Sub-County argued that government policies does not encourage their clients and this affects the financial performance of Sacco's. These findings agrees with the study done by Kamau (2010) which found that financial performance is affected by non-compliance to government policies. The study concluded that there are many conflicting policies from the ministry of cooperatives and Sasra which affects financial performance of Sacco's and that Sacco's are operating in financial distress which is affecting their financial performance. SACCO's should implement government policies in a way that will enhance Sacco's financial performance. The study recommended that Sacco's should develop internal policies that does not conflict SASRA policies. There is need to have polices for financial sustainability within Sacco's and be fully implemented.

\section{REFERENCES}

Bassem, B. (2008). Efficiency of Microfinance Institutions in the Mediterranean: An Application of DEA. Transition Studies Review. 15. 343-354. 10.1007/s11300-008-0012-7.

Bowie, et al. (1992). Ethics and Agency Theory: An Introduction. New York, Oxford University Press.

Chen, K. \& Chiivakal, M. (2008). What drives household borrowing and credit constraints. Evidence from Bonsai and Herzegovina.

Kamau, G. (2007). Assessment of Factors Influencing Operation of Sacco's. Case Study of Muhiga Teachers Sacco. 12-17.

Leonard, R. (2009). Financial factors influencing performance of Savings and Credit Cooperative Organization in Kenya. International Journal of Academic Research in Accounting, Finance and Management Sciences, Vol.4 (2),pp 295-206

Mulwa, J. (2013). Evaluation of the Performance of Savings and Credit Cooperative Societies; Kenya. International Journal of Management \& Information Technology.

Musyimi, J. (2010). Assessing Credit Access by Bee-keeping Farmers in Mwingi District. Technical Report. Nairobi.

Ndungu, T. (2010). Challenges and opportunities facing SACCOs in the current devolved system of government of Kenya: A case study of Mombasa County. International Journal of Social 
International Journal of Business Management and Economic Review

Vol. 3, No. 04; 2020

ISSN: 2581-4664

Sciences and Entrepreneurship, 1 (9), 288-314.

Omboi B. et.al. (2011). Factors that Influence the Demand for Credit for Credit among SmallScale Investors: a case study of Meru Central District, Kenya. Research Journal of Finance and Accounting, 2 (2).

Wong, K. (2010), Corporate Governance and Ethics. John Wiley and Sons Inc. 